\title{
GAMBARAN HISTOPATOLOGIK PAYUDARA MENCIT (Mus musculus) YANG DIINDUKSI BENZO( $\alpha)$ PYRENE DAN DIBERIKAN EKSTRAK KUNYIT (Curcuma longa L.)
}

\author{
${ }^{1}$ Eka M. Nansi \\ ${ }^{2}$ Meilany F. Durry \\ ${ }^{2}$ Carla Kairupan
}

\author{
${ }^{1}$ Kandidat Skripsi Fakultas Kedokteran Universitas Sam Ratulangi Manado \\ ${ }^{2}$ Bagian Patologi Anatomi Fakultas Kedokteran Universitas Sam Ratulangi \\ E-mail: Mnansi11_188@yahoo.com
}

\begin{abstract}
Breast cancer (Carcinoma mammae) is one of the most common cancers affecting women. The etiology of breast cancer is still unknown, however, there are several important risk factors linked to the occurence of breast cancer, as follows: genetic, hormonal, and environmental. Polycyclic aromatic hydrocarbons (PHA) such as benzo(a)pyrene is a carcinogenic agent that can be found in the surrounding environment. It has been proven that benzo(a)pyrene can induce tumors in experimental animal models. Turmeric is a natural biocompound that is often used to treat cancer due to its curcumin contents. Curcumin interacts with a variety of genetic molecules that undergo mutation in cancer. This study aimed to determine the effects of turmeric extract administration on the hispathological features of the breast of mice induced with benzo(a)pyrene. This was an experimental study using 15 female mice weighing 20-30g divided into 3 groups. Group A (negative control) was given standard food for 28 days and terminated on day 29. Group B (treatment I), the breasts were induced with benzo(a)pyrene subcutaneously for 14 days and the mice were terminated on day 29. Group C (treatment II), the breasts were induced with benzo(a)pyrene for 14 days and the mice were given the tumeric extract on day 15-28 and then terminated on day 29. Tissues were stained with hematoxylin eosin. The results showed that Group A had normal microscopic features of breast tissues. Group B showed PMN inflammatory cells, thickening layer of cuboidal epithelial cells surrounding the lactiferous ducts (>4 layers) as well as cells with coarse nucleus chromatin. Although mice in group $C$ still presented the PMN inflammatory cells, their cuboidal epithelial layers were thinner than that of group B (2-3 layers) and the cells contained rough nucleus chromatin. Conclusion: The histopathological features of the breast of benzo(a)pyrene induced mice administered with turmeric extract showed fewer layers of cuboidal epithelial cells with rough nucleus chromatin of the lactiferous duct cells wall compared to those treated with benzo(a)pyrene without turmeric extract.
\end{abstract}

Keywords: benzo(a)pyrene, turmeric, hyperplasia, breast

\footnotetext{
Abstrak: Kanker payudara (Carcinoma mammae) dikenal sebagai salah satu kanker yang paling sering menyerang kaum wanita. Penyebab pasti kanker payudara belum diketahui, namun ada beberapa faktor risiko yang penting dalam terjadinya kanker payudara yaitu keturunan, hormonal dan lingkungan. Senyawa hidrokarbon poliaromatik (HPA) merupakan karsinogen yang dapat ditemukan dalam lingkungan sekitar, contohnya ialah benzo( $\alpha$ )pyrene. Telah terbukti bahwa benzo( $\alpha$ )pyrene dapat menyebabkan tumor pada setiap model hewan percobaan. Beberapa pengobatan kanker sering melibatkan kunyit karena kandungan kurkuminnya yang dapat berinteraksi dengan berbagai molekul genetik yang bermutasi pada
} 
sel kanker. Penelitian ini bertujuan untuk mengetahui pengaruh pemberian ekstrak kunyit terhadap gambaran histopatologik payudara mencit yang diinduksi benzo( $\alpha)$ pyrene. Penelitian ini merupakan penelitian eksperimental laboratorik yang menggunakan mencit betina dengan berat 20-30g sebanyak 15 ekor, dibagi dalam 3 kelompok. Kelompok A (kontrol negatif), mencit diberi pelet standard selama 28 hari dan diterminasi pada hari ke-29. Kelompok B (perlakuan I), payudara mencit diinduksi benzo( $\alpha$ )pyrene secara subkutan selama 14 hari dan mencit diterminasi pada hari ke-29. Kelompok C (perlakuan II), payudara mencit diinduksi benzo( $\alpha$ )pyrene selama 14 hari dan mencit diberi ekstrak kunyit pada hari ke- 15-28 kemudian diterminasi pada hari ke-29. Jaringan diwarnai dengan hematoksilin eosin. Hasil penelitian menunjukkan pada kelompok A didapatkan gambaran mikroskopik jaringan payudara mencit yang normal. Pada kelompok B didapatkan adanya sel-sel radang PMN, penebalan lapisan sel epitel kuboid yang mengelilingi duktus laktiferi (>4 lapis) serta sel-sel dengan kromatin inti yang kasar, sedangkan pada kelompok $\mathrm{C}$ masih menunjukkan adanya sel-sel radang PMN, lapisan sel epitel kuboid yang tidak setebal pada kelompok B (2-3 lapis) serta kromatin inti sel yang kasar. Simpulan: Gambaran histopatologik payudara mencit yang diinduksi benzo $(\alpha)$ pyrene kemudian diberikan ekstrak kunyit menunjukkan jumlah lapisan sel epitel kuboid dengan kromatin inti kasar pada dinding duktus laktiferi tampak lebih sedikit dibandingkan dengan yang terlihat pada payudara mencit yang tidak diberikan ekstrak kunyit.

Kata kunci: benzo(a)pyrene, kunyit, hiperplasia, payudara.

Kanker payudara (Carcinoma mammae) dikenal sebagai salah satu kanker yang paling sering menyerang kaum wanita setelah kanker serviks. Kanker payudara juga dapat menyerang kaum laki-laki walaupun dengan angka yang sangat kecil (1:1000). ${ }^{1}$ Angka kejadian kanker payudara selalu bertambah setiap tahun, yaitu sekitar 1-2\% di sebagian besar negara di dunia. Kanker payudara merupakan salah satu kanker yang sering ditemukan di dunia dengan insidensi 20\% dari seluruh penyakit kanker. $^{2}$ Data dari Global Burden of Cancer (GLOBOCAN) tercatat pada tahun 2008 ada sekitar 2,8\% penduduk negara berkembang menderita kanker payudara dan 1,2\% meninggal karenanya. ${ }^{3}$

Penyebab pasti kanker payudara belum diketahui, namun ada beberapa faktor resiko yang penting dalam terjadinya kanker payudara yaitu keturunan, hormonal dan lingkungan. Sebuah studi menemukan adanya hubungan antara kanker payudara dengan paparan organic solvent tertentu dan hidrokarbon poliaromatik (HPA) seperti benzo( $\alpha$ )pyrene. Senyawa HPA merupakan karsinogen kimiawi yang mengandung siklikbenzena. Senyawa ini dapat membentuk struktur trisiklik, tetrasiklik atau pentasiklik yang berefek karsinogenik kuat sehingga dengan dosis kecil saja telah dapat menimbulkan kanker pada sel jaringan setempat. Senyawa HPA dapat ditemukan di lingkungan sekitar, terutama dari gas buangan industri, kendaraan bermotor dan asap rumah tangga. Ikan dan daging yang dibakar/dipanggang dengan menggunakan kayu atau arang juga mengandung kadar HPA yang tinggi. Telah terbukti bahwa benzo $(\alpha)$ pyrene dapat menyebabkan tumor pada setiap model hewan percobaan. Penelitian sebelumnya menunjukkan bahwa pemberian benzo( $\alpha$ )pyrene dosis 0,3mg/20gBB/hari selama 10 hari secara sub-kutan dapat menginduksi terjadinya kanker payudara mencit, dan konsumsi benzo( $\alpha)$ pyrene dengan dosis sebesar $120 \mathrm{ppm} / \mathrm{kgBB} /$ hari selama kurang dari 14 hari dapat menyebabkan kematian. ${ }^{4-7}$

Indonesia sering menggunakan obat herbal sebagai terapi alternatif untuk penyakit kanker yang salah satunya ialah kunyit. Kandungan kurkumin (pigmen kuning) yang dominan pada ekstrak kunyit dapat berinteraksi dengan berbagai molekul genetik yang bermutasi pada sel kanker payudara. Beberapa hasil penelitian telah menunjukkan bahwa kurkumin aman dan tidak toksik bila dikonsumsi. ${ }^{8,9}$ Berdasarkan hal-hal di atas, peneliti terdorong untuk meneliti tentang efek 
penggunaan ekstrak kunyit terhadap gambaran histopatologik payudara mencit yang diinduksi karsinogen $($ benzo $(\alpha)$ pyrene).

\section{METODE PENELITIAN}

Penelitian ini bersifat eksperimental laboratorik yang menggunakan mencit betina sebagai subjek penelitian. Mencit yang digunakan berjumlah 15 ekor yang berusia sekitar 3-4 bulan dengan berat badan antara 20-30g. Mencit dibagi dalam 3 kelompok (masing-masing kelompok terdiri dari 5 ekor mencit) dengan teknik pengambilan sampel secara acak (random). Semua menncit diberi makan pelet selama penelitian berlangsung. Kelompok A (kontrol negatif), mencit tidak diberi perlakuan dan diterminasi pada hari ke-29. Kelompok B (perlakuan I), payudara mencit diinduksi dengan benzo $(\alpha)$ pyrene secara subkutan selama 14 hari, kemudian tidak diberi perlakuan hingga hari ke-28 dan pada hari ke-29 mencit diterminasi. Kelompok C (perlakuan II), payudara mencit diinduksi benzo( $\alpha)$ pyrene selama 14 hari kemudian diberikan ekstrak kunyit pada hari ke 15-28 dan diterminasi pada hari ke-29. Untuk pemeriksaan gambaran histologik jaringan payudara digunakan pewarnaan hematoksilin eosin.

\section{Prosedur Penelitian \\ Ekstrak kunyit}

Penentuan dosis kunyit didasarkan pada penelitian terdahulu oleh Prakoso dkk (2008), dimana dosis yang diberikan pada tikus ialah 100mg/kgBB. Selanjutnya, dilakukan perhitungan berdasarkan faktor konversi dosis untuk jenis hewan dan manusia, yaitu dosis ekstrak kunyit sebanyak 20mg diberikan pada tikus yang beratnya $200 \mathrm{~g}$ setara dengan 2,8mg untuk mencit yang beratnya 20g. Dosis ekstrak kunyit yang diberikan pada mencit dalam satu hari ialah 3mg. ${ }^{10}$ Ekstrak kunyit 3mg dibuat menjadi bentuk larutan ekstrak 0,3ml dan diberikan per oral dengan menggunakan sonde.

\section{Larutan benzo(a)pyrene}

Larutan benzo( $\alpha)$ pyrene dibuat dengan cara melarutkan $100 \mathrm{mg}$ serbuk benzo( $\alpha)$ pyrene dengan $100 \mathrm{ml}$ minyak zaitun. Pada penelitian ini diperlukan larutan benzo $(\alpha)$ pyrene sebanyak 0,3mg/20g/hari selama 14 hari. ${ }^{7,11}$ Larutan benzo( $\alpha$ )pyrene diberikan pada hewan uji dengan cara injeksi subkutan pada daerah payudara kanan.

\section{HASIL PENELITIAN \\ Kelompok A (Kontrol Negatif)}

Gambaran mikroskopik payudara mencit kelompok A (Gambar 1a dan 1b) menunjukkan duktus laktiferus yang dilapisi 1-2 lapis epitel kuboid normal serta dikelilingi jaringan ikat dan jaringan lemak yang normal.

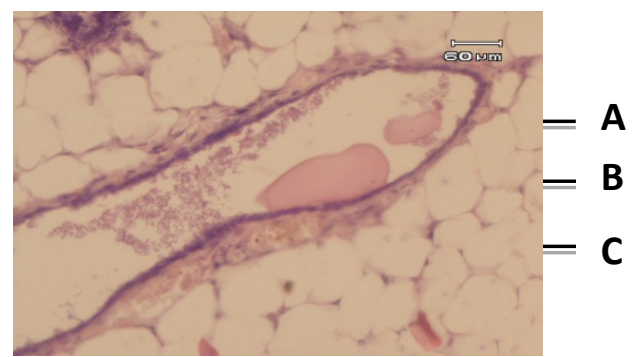

Gambar 1a. Gambaran mikroskopik payudara mencit kelompok A. Tampak duktus laktiferi (A) yang dilapisi epitel kuboid (B) dengan adanya jaringan ikat (C) yang normal (100 x).

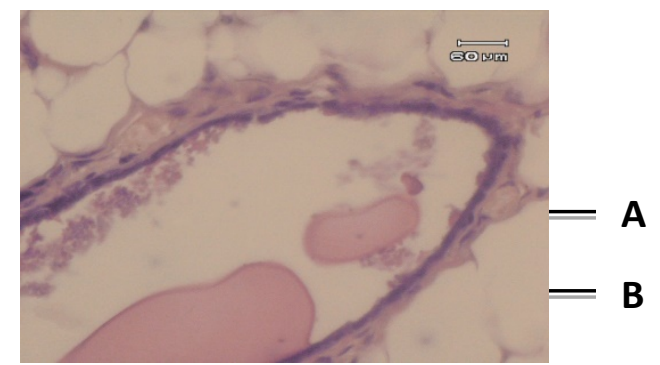

Gambar 1b. Gambaran mikroskopik payudara mencit kelompok A (kontrol negatif). Tampak terdapat 1-2 lapis epitel kuboid normal (A) yang mengelilingi duktus laktiferi (B) (400 x).

\section{Kelompok B (Perlakuan I)}

Gambaran mikroskopik payudara mencit kelompok ini menunjukkan adanya sel-sel radang yaitu PMN yang tidak dijumpai pada kelompok kontrol negatif, 
penebalan lapisan sel epitel kuboid yang mengelilingi duktus laktiferi ( $>4$ lapis) serta sel-sel dengan kromatin inti yang tampak kasar (Gambar 2a dan 2b).

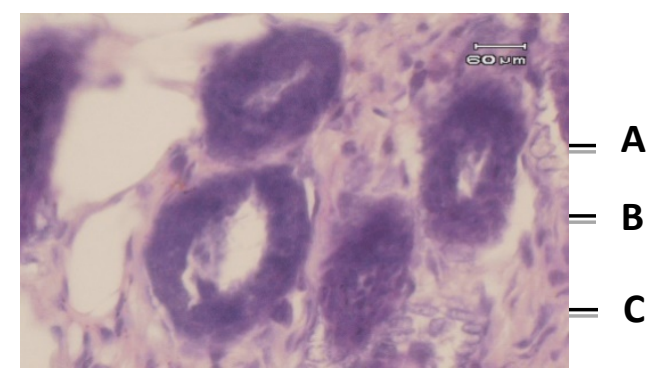

Gambar 2a. Gambaran mikroskopik payudara mencit kelompok B. Tampak sel-sel radang PMN disekitar jaringan ikat (A), lapisan sel epitel kuboid tebal ( $>4$ lapis) mengelilingi duktus laktiferi (B) dan sel-sel dengan kromatin inti kasar (C) (100 x).

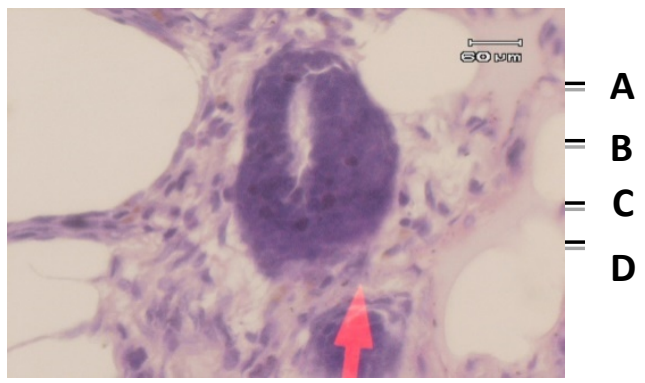

Gambar 2b. Gambaran mikroskopik payudara mencit kelompok B (perlakuan II).. Tampak hiperplasia lapisan epitel kuboid (A) yang mengelilingi duktus laktiferi (B). Tampak juga sel-sel radang PMN (C) serta sel dengan kromatin inti kasar (D) (400 x).

\section{Kelompok C (Perlakuan II)}

Gambaran mikroskopik payudara mencit kelompok $\mathrm{C}$ menunjukkan adanya sel-sel radang limfosit dan PMN pada jaringan ikat, 2-3 lapis sel epitel kuboid yang mengelilingi duktus laktiferi dimana lapisan epitel ini nampak tidak setebal pada kelompok B serta adanya kromatin inti sel yang kasar (Gambar 3a dan 3b).

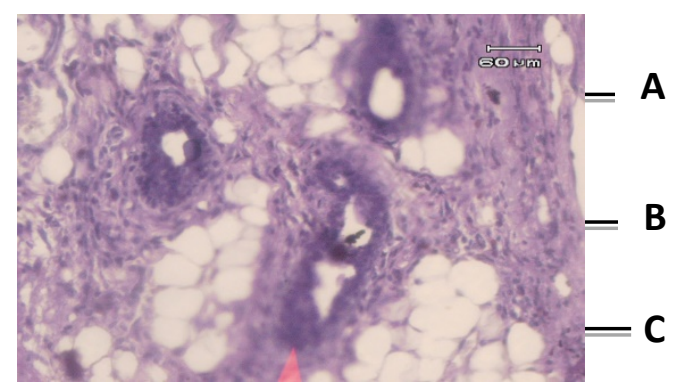

Gambar 3a. Gambaran mikroskopik payudara mencit kelompok C (perlakuan II). Tampak adanya sel-sel radang PMN (A) serta duktus laktiferi (B) yang dilapisi 2-3 lapis epitel kuboid (C) (100 x).

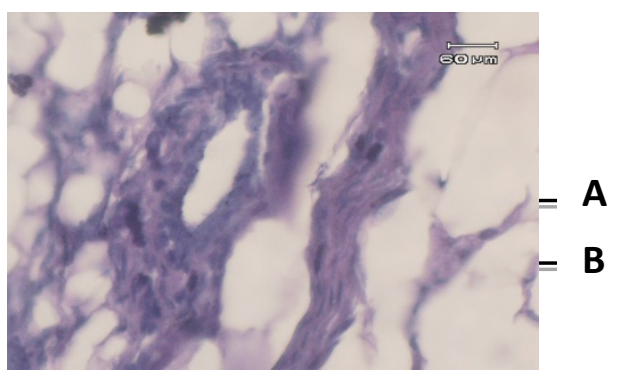

Gambar 3b. Gambaran mikroskopik payudara mencit kelompok C (perlakuan II). Tampak adanya lapisan epitel kuboid (2-3 lapis) (A) serta kromatin inti sel yang kasar (B) (400 x).

\section{BAHASAN}

Penelitian ini memberikan data mengenai efek pemberian ekstrak kunyit terhadap gambaran histopatologik payudara mencit yang diinduksi benzo( $\alpha)$ pyrene.

Mencit-mencit pada kelompok A (kontrol negatif), yaitu mencit yang tidak diberi perlakuan apapun dan hanya diberikan makanan berupa pelet standard, menunjukkan gambaran mikroskopik dengan adanya duktus laktiferi yang dilapisi oleh 1-2 lapis epitel kuboid yang tersusun rapi dan rapat serta adanya jaringan ikat yang normal.

Berbeda dengan mencit-mencit pada kelompok A, mencit-mencit yang diinduksi benzo( $\alpha$ )pyrene dosis $0,3 \mathrm{mg} / 20 \mathrm{~g} / \mathrm{hari}$ selama 14 hari (kelompok B atau perlakuan I) menunjukkan adanya gambaran mikroskopik yang tidak normal, yaitu ditemukannya tanda-tanda awal pertumbuhan dan perkembangan ke arah tumor ganas berupa hiperplasia sel-sel epitel kuboid yang melapisi dinding duktus laktiferi disertai gambaran kromatin inti yang kasar sehingga dinding duktus tampak lebih tebal (>4 lapisan sel) dan warna lebih gelap. Juga ditemukan sel-sel radang PMN yang menyebar disekitar jaringan ikat. Perubahan pada gambaran payudara mencit ini dapat terjadi akibat benzo $(\alpha)$ pyrene yang diinduksikan kemudian menjadi aktif berupa reaksi epoksida setelah 
dimetabolisme di dalam tubuh. Zat aktif yang terbentuk tersebut mengakibatkan perubahan pada DNA berupa mutasi gen. ${ }^{12}$ Benzo $(\alpha)$ pyrene akan menjadi karsinogen aktif pada lokasi dimana dia dimetabolisme dan dapat memicu terjadinya neoplasma pada daerah tersebut. ${ }^{12}$ Gambaran mikroskopik yang didapatkan pada mencit kelompok ini masih belum terlihat gambaran kanker yang invasif karena perubahan yang terjadi masih dibatasi membran basal dan tidak menginvasi stroma atau saluran limfovaskular. Sesuai dengan penelitian sebelumnya yang dilakukan oleh Samosir (2014), ${ }^{11}$ pemberian benzo $(\alpha)$ pyrene dosis $0,3 \mathrm{mg} / 20 \mathrm{~g} /$ hari secara subkutan selama 14 hari sudah menunjukkan terjadinya neoplasma jinak berupa fibroadenoma yang tersusun dari jaringan penghubung dan selsel epitel payudara. Pada penelitian tersebut terjadi hiperplasia yang tampak menonjol pada jaringan ikat hingga jaringan ikat tersebut menutupi duktus-duktus di sekitarnya. $^{11}$

Hasil yang menarik terlihat pada payudara mencit yang diberikan ekstrak kunyit dosis $0,3 \mathrm{ml} / 20 \mathrm{~g} /$ hari selama 14 hari setelah diinduksi benzo( $\alpha)$ pyrene dosis 0,3mg/20g/hari selama 14 hari (kelompok C atau perlakuan II). Secara mikroskopik payudara mencit pada kelompok ini masih menunjukkan adanya sel-sel radang PMN pada jaringan ikat sekitar, namun jumlah lapisan sel epitel kuboid berkromatin inti kasar yang mengelilingi duktus laktiferi berkurang (2-3 lapis) dibandingkan dengan yang terlihat pada kelompok mencit yang tidak diberikan ekstrak kunyit setelah diinduksi benzo( $\alpha$ pyrene. Hal ini menunjukkan adanya penghambatan proliferasi sel dan induksi eliminasi sel-sel yang rusak/abnormal (apoptosis). Kurkumin yang terkandung dalam ekstrak kunyit bekerja sebagai penangkal radikal bebas dan antioksidan yang dapat menghambat proses metabolisme karsinogen menjadi bentuk aktif dalam tubuh. Kurkumin juga berperan sebagai inhibitor siklooksigenase dapat mencegah produksi prostanoid yang berlebih sehingga mengurangi reaksi inflamasi dan proliferasi sel serta memacu apoptosis. Efek kurkumin sebagai antiproliferatif yaitu menghambat ekspresi c-myc yang merupakan gen pemacu proliferasi, sedangkan sebagai pemacu apoptosis kurkumin diketahui dapat meningkatkan aktivitas gen $p 53$. Gen p53 yang merupakan protein supresor tumor dan regulator yang diaktivasi jika terdapat kerusakan pada DNA atau stres tertentu pada sel. ${ }^{9,13}$

Penelitian sebelumnya yang dilakukan oleh Huang dkk (1992) ${ }^{14}$ bahwa pemberian ekstraksi kunyit (kurkumin) pada punggung mencit mampu menghambat pembentukan tumor kulit yang terinduksi benzo( $\alpha)$ pyrene. Penelitian yang dilakukan ini juga telah memberikan suatu bukti bahwa ekstrak kunyit dapat menghambat pertumbuhan dan perkembangan kanker payudara (karsinogenesis) pada mencit yang diinduksi benzo( $\alpha$ )pyrene yang terlihat pada gambaran histopatologiknya.

\section{UCAPAN TERIMAKASIH}

Ucapan terima kasih disampaikan kepada dr. Jane Wuisan Sp.F-K serta dr Poppy M. Lintong Sp.PA-K yang telah memberikan kritikan dan saran, serta semua pihak, baik secara langsung maupun tidak langsung, yang telah memberikan ide dan gagasan kepada penulis.

\section{SIMPULAN}

Gambaran histopatologik payudara mencit yang diinduksi benzo $(\alpha)$ pyrene kemudian diberikan ekstrak kunyit menunjukkan jumlah lapisan sel epitel kuboid dengan kromatin inti kasar pada dinding duktus laktiferi tampak lebih sedikit dibandingkan dengan yang terlihat pada payudara mencit yang tidak diberikan ekstrak kunyit.

\section{SARAN}

1. Pada penelitian berikutnya dapat dilakukan penambahan jumlah sampel.

2. Pada penelitian selanjutnya dapat diperhitungkan mengenai penambahan waktu penelitian. 
3. Pada penelitian selanjutnya, pemberian ekstrak dapat dibuat dengan dosis bertingkat untuk mendapatkan dosis ekstrak kunyit yang paling efektif.

\section{DAFTAR PUSTAKA}

1. Mulyani NS, Nuryani. Kanker payudara. Editor: Hakki, Isna. Kanker payudara dan penyakit menular seksual pada kehamilan. Ed 1. Yogyakarta: Nuha Medika; 2013. p.1-96.

2. Khairinal. Efek kurkumin terhadap proliferasi sel limfosit dari limpa mencit $\mathrm{C} 3 \mathrm{H}$ bertumor payudara secra invitro. [Thesis]. Depok: Universitas Indonesia; 2012.

3. Salim M, Susanto A, Stefanus D. Terapi nonpartikel albumin-kurkumin atasi kanker payudara multidrug resistant. CDK. 2014;41: p.710

4. Yani EV, Nurhidayah RE. Pengetahuan penderita kanker tentang kemoterapi di rumah sakit umum pusat Haji Adam Malik Medan. Farmasi. 2005;1: p.1-4.

5. Sitorus MS. Imunoekspresi ki-67 pada tumor payudara tikus wiatar yang diinokulasi tumor terinduksi benzo(a)pyrene dan diberikan ekstrak daun sirsak. [Thesis]. Medan: Universitas Sumatera Utara; 2013.

6. Fujin C, Wei F, Jinhua $H$, Wei $L$, Donggen L, Guoyi L, et al. Etiologi tumor. Editor: Desen W, Tiehua W, Yixin Z, Zongyuan Z, Jingqing L, Yilong W, et al. Onkologi klinis. Ed 2. Jakarta: FKUI; 2008.p.27-43.

7. Anggraini DR. Ekspresi imunohistokimia ki-67 pada tumor payudara tikus wistar yang diinduksi kanker terinduksi benzo $(\alpha)$ pyrene dengan pemberian ekstrak benalu teh. [Thesis]. Medan: Universitas Sumatera Utara; 2013.

8. Radji M, Aldrat H, Harahap Y, Irawan C. Uji sitotoksisitas buah merah, mahkota dewa dan temu putih terhadap sel kanker serviks. Farmasi. 2010;5: p.41-47.

9. Nurrochmad A. Pandangan baru kurkumin dan aktifitasnya sebagai antikanker. Biofarmasi. 2004;2(2): p.1-4.

10.Prakoso B. Pengaruh pemberian ekstrak kunyit (curcuma domestica) terhadap gambaran mikroskopis ginjal mencit $\mathrm{Balb} / \mathrm{c}$ yang diberi parasetamol. Histologi. 2008; p.7-8.

11.Samosir AA. Pengaruh ekstrak etanol daun bangun-bangun (plectranthus amboinicus (lour) spreng) terhadap penghambat karsinogenesis mammae mencit betina yang diinduksi benzo $(\alpha)$ pyrene. 2014;2: p.1-6.

12.Kanoko M. Neoplasma. Editor: Pringgoutomo S, Himawan S, Tjarta A. Patologi I (umum). Ed 1. Jakarta: Sagung Seto; 2006. p.171-238.

13.Tanu I. Analgesik-antipiretik, analgesikantiinflamasi nonsteroid dan obat gangguan sendi lainnya. Editor: Zubaidi J, Handoko T. Farmakologi dan terapi. Ed 5. Jakarta: FKUI; 2011. p.230-2.

14.Huang MT, Wang ZW, Georgiadis CA, Laskin JD, Coney AH. Inhibitory effect curcumin on tumor inititation by benzo $(\alpha)$ pyrene and 7, 12dimethylbenz $(\alpha)$ anthracene. Carcinogenesis. 1992;13: p.947-954. 